\title{
第13回. 日本大腸肛門病学会北海道地方会
}

日 時: 平成 4 年 10 月 17 日 (土） $13: 30 \sim 16: 45$
会 場 : 山之内製薬大通ビル $9 \mathrm{~F}$ 会議室
会 長: 札幌医大 名誉教授 早坂 滉

\section{1. 直腸膀脱瘦の 2 例}

\author{
道立紋别病院外科 \\ 中野 昌志，八十島孝博，奥 雅志 \\ 白松 幸爾 \\ 札幌医科大学第 1 外科 \\ 平田 公一
}

今回われわれは，最近 1 年間で直腸膀腅瘦 2 例を経験 したので報告する．症例 $1 ： 60$ 歳，女性. 数年来，下 浰, 粪尿を認め, 他院にて膀胱炎の診断で治療をうけて いた，上記症状が軽快せず，血尿，微熱等の症状も出現 し，当院内科受診. ガストログラフィンによる注腸造影 にて直腸膀胱瘻の診断をうけ，手術を目的として当科入 院. 開腹所見は直腸 $(\mathrm{Ra} \sim \mathrm{Rs})$ と膀胱の間に瘉着・瘦 孔を䜅め, 瘦孔切除術を施行した. 退院後の経過は良好 である. 症例 $2: 59$ 歳，女性，平成 4 年 5 月，上腹部痛 と血便学主訴として当院内科受診. 注腸 $\mathrm{Ba}, \mathrm{CT}$, 膀腅 鏡などの検查にて直腸膀胱瘦と診断された. 当科入院時 には自覚症状なし，開腹所見は值晹膀胱閒の瘾着を認 め, 術中大腸ファイバーにて直晹の瘎孔を確認し，瘦孔 切除術，直腸壁開鎖術を施行した，術後経過は良好であ る. 今回の 2 症例住, 既往歷化子宮全摘術があり, 直腸 膀胱樭はそれに起因するものと考えられた．上記 2 例を 報告するとともに若干の文献的考察を述べる．

\section{2. 直腸脱に対する Gant-三輪+Thiersch 变法の検討} 一術後アンケート調查を中心に一

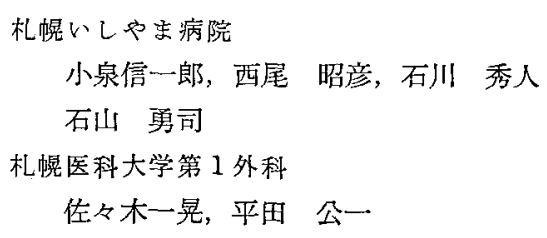

1985年〜 1991年の間に当院で完全直腸脱130例の治療 を行ってきたこのうち101例に Gant-三輪法とナイロ ン系を用いた Thiersch 変法の併用手術を施行した。 こ の101例に対して術後成績の追跡調查を行ったので報告
する.調租の内容：(1)全体としての改善度，満足度. (2) 脱出, 下着の污れ, 肛門のしまり, 便の出にくさ, 残便 感の改善度. (3)現在ある愁訴などである，回答は 68 例 （67\%）から得た。(1)全体としての満足度は，手術を受 けて大変良かった56例 (83\%), 良かった8例（12\%), 変わりなし 3 例 $(4 \%)$ ，悪くなった 1 例（1％）であ った. (2)改善度では，脱出に対しての改善が $76 \%$ とっ とも良く，(3)現在もある愁訴では軽い脱出が 6 例（9 $\%$ ，下着の污れが 5 例 ( $7 \%)$ ，肛門のしまりの鳃さ 6 例 ( $9 \%)$, 便が出にくい20例 (29\%), 残便感12例 (17 \%)などであった。またまったく愁訴なしと回答したも のが14例 (20\%) であった. 再手術施行は 2 例（3\%） であった．直腸脱に対する Gant-三輸十Thiersch 変法 は，本疾患济対し第 1 選抧となると考えている.

3. Fournier's Syndrome 様の蜂窩織炎をきたした 化膿性汗腺炎の 1 治駼例

地川武田病院 武田 新生

痔瘦の根治手術のため入院の 27 歳, 男性で, 肛門周 因，右陰鸾，尾骨部乞順次膿演形成し切開を繰返した。 桾康病はなく，また免疫，血液学的にも問題はなかった が, Fournier's Syndrome 様に病状が進展した。若干 の文献的考察を加え報告する. 


\section{Peutz-Jeghers 症候群の 1 例}

札晅厚生病院消化器科

國田 芳敬, 加藤 茂治, 加 藤 学 佐藤 洋一，長川 達哉，夏井 清人 佐藤 隆啓, 東 野 清, 杤原 正博 宮川 宏之，小井戸一光，藤 永 明 今村 哲理，八百坂 透，須賀 俊博 村島 義男

同 小児科

今野武津子

同 病理

任藤 利宏

今回われわれは，大腸の過誤腫性ポリープと，口唇の メラニン沈着をきたした Peutz-Jegher 症候群（以下 $\mathrm{P}-\mathrm{J}$ 症候群）のI例を 経験したので 報告する．症例 は，11カ月の女児. 主訴は肛門より脱出するポリープ で，精查目的のため当院に入院した. 内視鏡検查で $\mathrm{Rb}$ 前壁に大小 3 個のポリープを認め, ポリペクトミーを実 施した. 病理組織上 $\mathrm{P}-\mathrm{J}$ 型ポリープと診断され，退院 6 カ月後に口唇のメラニン沈着を認めたため, $\mathrm{P}-\mathrm{J}$ 症 候群と診断した。

5. 潰瘍性大腸炎に対する Predonisolone gel 注腸 療法

旭川医科大学第 3 内科

垂石 正樹，蘆田 知史，綾部 時芳

斉藤 裕輔, 野村 昌史, 渡 二 郎

柴田 好, 並木 正義

旭川医科大学付属病院薬郕部

千葉薰

潰瘍性大腸炎（UC）に対する局所㙩法としては，從 来方ら predonisolone (PSL) 生食に溶解した注腸療 法（PSL 注腸）が行われている．今回，新しい試みと して PSL 含有 gel (PSL gel) を作製し，その注腸療 法の効果を検討した，対象は直腸・S 状結腸に活動性病 変を有する UC 5 例（男 2 例，女 3 例），年齢は16歳 57 歳で, 左侧結腸炎型 2 例, 直腸・S 状結腸炎型 3 例. 重 症度は軽症が 1 例，中等症 4 例で初発例の 1 例以外は再 燃緩解型であった，使用した gel は，2〜3\%の car boxy methyl cellulose-Na 基剂とした gel に PSL を0.3 0.5mg/ml の割合で混合した。本療法開始前の 治療はそのまま継続し，PSL として $20 \mathrm{mg} / \mathrm{day}$ を 2 回 に分割して注腸投与した．投与前，投与後 2 週の臨床症 状，内視鏡所見を比較した結果，全例に改善がみられ， 直腸・S 状結腸に対士る PSL gel 注晹療法の有用性が
示された. gel の注腸は従来 PSL 注腸と比較して便意 の出現がほとんどなく，在宅での自己注入も可能である などの長所があり，今後 UC に対し試みるべき新しい 治療法と考える.

\section{6. 上行結腸の遊離が原因と思われたイレウスの 1 例}

白老町立病院外科

匹十九院正道，阿部 俊英

札幌医科大学第 1 外科

平田 公一

今回われわれは，イレウスによる入退院を繰り返しを の原因が上行結腸が後腹膜から遊離しておりさらに急性 虫垂炎術後の回盲部の瘜着のため上行結腸が湮着部で折 れ曲がることが原因と思われるイレウスを術前に診断 し，上行結腸を後腹膜に固定する術式で良好な結果が得 られたので報告する。この症例は 2 回目の入院時に癒着 剝離術を施行しているが思わしい結果が得られず，入退 院を繰り返していた，そのたびに保存的治療でイレウス は解除していたが，外来通院中も腹痛の主訴は消えず， 整腸剤等の選択に苦虑した． 5 回目の入院時に，ガスト ログラフィンによる追跡消化管造影を施行した。この時 の立位と臥位との比較比より上記のような原因を推定し た

\section{7. 大腸多発癌についての臨床的検討}

恵佑会札县病院内科

小端 順一, 崔 公賢, 清水 勇一 河原崎 啺, 塚越 洋元

同外科

平 野 聡，久須美貴哉，竹 馬 彰 金子 行宏，菅野 紀明，川村 健 細川 正夫

平成 1 年 平成 3 年 12 月まで当科で経験した大腸多発 癌核男性 36 人，女性 20 人であった，同時性が55人，異時 性が 1 人であり，大きさ衫 $1 \mathrm{~cm} \sim 2 \mathrm{~cm}$ 末満が $30.7 \%$ と 一番多かった．部位別では，S状結腸に多く，ついで直 腸に多い，同一区域もしくは隣接区域に発生したのは， $33.9 \%$ であった，組織別では高分化型腺癌が $66.4 \%$ ，っ いで中分化型腺癌が $25.2 \%$ あった，進行度の組み合せ では，進行癌十早期癌の組み合せが $60.7 \%$ と一番多かっ た。同時性多発癌の発生は $\mathrm{S}$ 状結腸に多く， S 状結腸に 癌を認めた時には，多発癌を念頭におき，十分に大腸検 索をすることが必要である。 


\section{8. 陰部潰瘍を合併したクローン病の 1 例}

札幌医科大学第 1 内科

岡田 至全，伊東 文生，伊藤 和江 金戸 宏行，黒 河 聖，遠藤 圭介 久野 和成，澒／田明範，本谷 聡 坂本 裕史, 得 地 茂, 杉山 敏郎 菅 充生, 矢花 剛, 谷内 昭 天使病院第 2 内科

辻崎 正幸，伊林由美子，戸次 英一 太黒胃腸科病院

今井 希一, 高杉 英郎, 諸 岡 透

緒岡 忠夫, 太 黒 崇

症例は 39 歳, 女性. 平成 2 年 9 月より下㰾, 腹痛, 発 熱出現し; 近医受診. 大腸内視鏡下生検にて類上皮性肉 芽腫を認め，クローン病と診断された。平成 3 年 9 月よ り，外陰部潰瘍，口腔内アフタ出現し，同年12月精查の ため当科入院となった．入院後の大腸内視鏡検查にてア フタ様潰瘳，炎症性ポリポーシスを認め，クローン病に 矛盾しない所見が得られた。クローン病に陰部潰惶が合 併することは稀であり興味ある1例として報告する。

\section{9. 大腸秝室穿孔例の検討}

日鋼記念病院外科

小橋 重親，勝木 良雄，山本 浩史 安藤 修敏, 有山悌三, 蓮実透 辻 窝 重, 安田 隆義, 西村 昭男

最近 9 年間で日鋼記念病院外科で経䍄した大腸䄸室穿 孔例は11例であった，㮩室の部位は右側 7 例（忘腸 2 例，上行結腸 5 例)，左侧 4 例（下行結腸 1 例， $\mathrm{S}$ 状結 腸 2 例, 直腸 1 例）であった. 性別は男性 8 名, 女性 3 名, 年齢は 30 歳から 68 歳で, 比較的若年者に多かった. 右側結腸例では 7 例中 2 例が虫金炎々診断されていた. 㓤室穿孔と診断した 5 例中 3 例佉注腸造影が非常に有勃 であった．左側例恬 4 例中 3 例が汎発性腹膜炎の㟝断で 緊急手術を施行されていた。治療は手術10例，保疜療法 1 例であった. 手術例は全例術後経過は良好であった。 大腸息室症例に扝いては，保存療法と手術の選択，“た 保存療法から手術へいっ切り替えるかが重要と思われ た.

\section{0.びまん浸潤型大腸癌の 2 症例}

\author{
東札幌病院外科 \\ 水島 康博，秋山 守文，植田 隆一 \\ 札瀑医科大学第 1 外科 \\ 唐沢 学洋
}

びまん浸潤型大腸癌は比較的若年層に生じる予後不良 の癌として最近報告例が増加している．今回， S 状絬腸 に発生した 2 症例を経験したので報告する. 症例 1：43 歳，男性，主訴は腰痛，下痢，血便．Ｓ状結腸に約 $20 \mathrm{~cm}$ の辺縁不整の狭窄あり，生検にて group 5. 両鎖骨上 リンパ節転移と多発性骨転移を認める． $\mathrm{H}_{0}, \mathrm{P}_{0}, \mathrm{~N}_{4}$ (+). S 状結腸切除術 $\left(\mathrm{R}_{3}\right)$ 施行. 低分化腺癌で $\mathrm{S}$, $\mathrm{ly}_{3}, \mathrm{v}_{2}, \mathrm{n}_{4}(+)$. 少後 $5 \mathrm{FU} 500 \mathrm{mg} /$ 日， 8 週間持続静 注により，腰痛消失，鎖骨上リンパ節転移も消失し，退 院. $5 \mathrm{FU} 200 \mathrm{mg} /$ 日経口投与としたが 1 力月後，めま 々，頭痛，嘔吐あり，CT 亿て多発性脳転移あり再入 院. $5 \mathrm{FU} 500 \mathrm{mg} /$ 日持続静注再開にて，症状消失．症 例 $2: 47$ 歳, 男性. 主訴は下腹部痛, 便秘. $\mathrm{S}$ 状結腸に 約 $12 \mathrm{~cm}$ にわたり辺縁不整の狭窄あり，生検にて group 5. CT 上, 多発肝転移あり, 疼痛のコントロールとフル ツロン $1200 \mathrm{mg} /$ 日の内服を行ったが，イレウス症状っよ くハルトマンの手術を施行. $\mathrm{H}_{3}, \mathrm{P}_{1}, \mathrm{~N}_{4}(+)$. 低分化 腺癌で, $\mathrm{S}, \mathrm{Iy}_{3}, \mathrm{v} 2, \mathrm{n}_{3}(+)$. 腹腔内 $\mathrm{MMC} 16 \mathrm{mg}$ 散 布. 術後, 経口提取可能となるも， 7 日目より肝不全と なり，術後13日目に死亡した。

\section{1、MTX/5-FU 交代療法が有効であった大腸癌の 1} 例

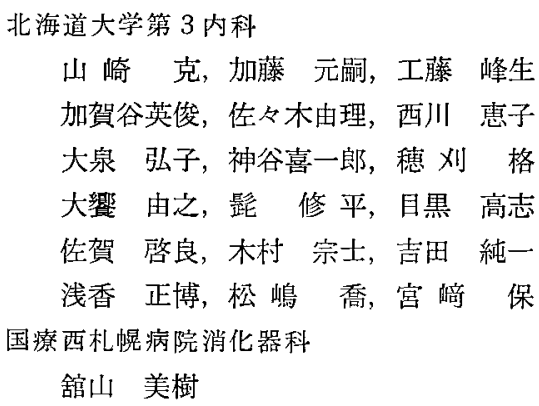

近年, biochemical modulation の考え方に基つくく癌 化学療法が注目を浴びてきているが，今回われわれは， MTX/5-FU 交代療法が有効であった大腸癌の症例を経 験したので報告する．症例は45歳の女性で，1991年11月 下旬より市腹部痛・腰痛が出現，12月 26 日当科初診し， 腹部超音波・CT にて肝全域に多発性腫晹を認め，精查 加療目的で入院となる. 注腸 $\mathrm{X}$ 線・大腸内視鏡では $\mathrm{S}$ 状 結腸に約1.6 cm の Borrmann1型様の腫瘍を認め, EUS 
では浸達度 S で病理学的には中分化腺癌と診断された。 多発性肝転移が存在するために化学療法が選択され， 1992年1月17日より MTX 150mg +5-FU 900 mg+ Leucovorin 90mgを週 1 回 5 クール施行したところ, 大腸病変は平坦型へ縮小し肝病变も著明な縮小を認め PR と判定した. その後は腫湟堌覀のため 4 力月後に死 亡したが，一時的にも腫演縮小効果が認められ，試みら れてよい治療法の一つと考えられた。

\section{2. 直腸肛門部悪性黑色腫の 1 例}

带広厚生病院外科

村木 専一，三浦 哲哉，大竹 節之

日下 貴文, 竹之内伸郎, 藤 森 勝

関下 芳明, 塩野 恒夫, 黒島振重郎 带広厚生病院病理

山口㵎

今回的れわれ流，直腸肛門部に原発した 1 症例を経験 したので報告する。症例は64歳, 男性. 1990年 9 月より 下血出現. 1991年 3 月当科受診、直腸㣫湐の診断となる が，本人手術拒否し来院せず．1991年 8 月排便障害が出 現したため当科再診し手術目的入院となる. 再診時所見 は，腫瘍の大きさは約 $\phi 5 \mathrm{~cm}$ ，隆起型で，腹圧をかける と腫瘍が肛門より脱出．全身比転移性皮下腫瘤，CT て多発性肝転移あり．悪性黒色腫の診断にて，9月12日 直腸切断，人工肛門造設術施行. 1992年 5 月 6 日脳転移 悪化し再入院.VBD 療法施行したが，6月29日死しし た.

\section{3. 大腸 sm 癌の臨床病理学的検討}

旭川厚生病院外科

佐藤 裕二, 藤沢 純爾, 飯 田. 博

澤口 裕二, 稲 葉 聡, 間宮 規章

広瀬 邦広, 川村 秀樹, 菅原 俊道

浅間 俊之

同 病理

近藤 信夫

目的および方法 : 1980年 1 月〜 1992年 3 月に切除され た大腸癌556例中， sm 癌は27例 (4.9\%) である. sm 㽟 について臨床病理学的に検討した。結果および結諭 : 27 例中 S 状結腸以下が20例（74.1\%） と下部に多くみら れ, 組織型では高分化18例, 中分化 9 例であった. 形態 学的には隆起型16，表面型11例で，表面型は隆起型に比 して小さく, 深達度も深く, 中分化腺癌が多い傾向にあ った。また27例の $\mathrm{ly}(+) 33.3 \%, \mathrm{v}(+) 14.8 \%, \mathrm{n}$

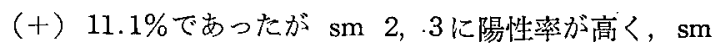
2，3のものは腸管切除が望ましいと考えられた.

\section{4. 下部直腸 $\mathrm{pm}$ 癌の検討}

札沅医科大学第 1 外科

木村 雅美, 任々木一晃, 江副 英理

龟嶋 秀和, 蔦井 克典, 山城 一弘

山本 雄治, 桂 巻 正, 三神 俊彦

筒井 完, 平田 公一

最近の14年間に教室で経験した下部直腸 $\mathrm{pm}$ 潞67例 を対象とし検討した。同時期の $\mathrm{pm}$ 大腸癌は128例で $52.3 \%$ 占めた．結果：手術術式は，直晹切断術が 45 例 (67.2\%) を占めた．括約筋温存手術は16例，経仙骨的 局立切除術は 4 例であった．組織型住高分化腺癌が53.7 \%を占め，低分化腺痁は1例のみであった．リンパ節郭 清は, 局所切除の 4 例を除くと全例上方郭清は 3 群まで 行い，側方は R 1：20例， R 2:27例， R 3:16例であ った.リンパ節転移は21例 $(31.3 \%)$ で，このうち側方 リンパ節転移纹 2 例のみであった．治癒切除術が 63 例 に, 相対的非治澺切除術が 4 例であった. 5 年生存率は 約 $83 \%$ であった。再発は12例にみられ，血行性転移が 7 例 (肝： 3 例, 肺: 2 例, 骨: 2 例), 腹膜 - 局所再発 が 7 例であった，局所再発全例で側方郭清は $\mathrm{n}<\mathrm{R}$ で あった，再発発見時期は，血行性転移で12-50力月，腹 膜・局所で 6 〜23力であった．局所切除術例は 4 例と も生存中である：まとめ：リンパ節転移は $31.3 \%$ に認め られたが，この半数以上は $\mathrm{n} 1$ 陽性であり，側方転移 は2例のみであった.リンパ節郭清は神経温存が可能と 考えられた。

\section{5. 直腸癌の括約筋温存術後吻合部再発の検討}

市立札兟病院外科

河村 勝義, 中西 一彰, 脇坂 好孝

小池 能宣, 尾崎 進, 佳野, 秀一

岩永 力三, 中西 昌美

近年直晹癌に対する括約筋温存手術は基本術式として 確立された感があるが，われわれは括約筋温存術後比較 的早期に吻合部再発を認めた 3 例を経験したので報告す る. 症例 $1 ： 70$ 歳, 男性. 1990年 1 月 Rs Ra, circ, 2 型に対し低位前方切除術施行. ss, ly $y_{1}, v_{0}, n_{0}$, ow (-), aw (一), ew (一). 初回手術10力月後下血あり, 吻合 部直上儿 2 型腫序認为，1991年 1 月再手術施行. 腫瘍は 膀胱に直接浸㵎し切除不能にて S 状結腸に stoma 造設. 症例 $2: 47$ 歳，女性. 1989年12月 Rs, It，2 型に対し低 位前方切除施行. pm, lyo, $\mathrm{v}_{0}, \mathrm{n}_{0}$, ow (-), aw (-), ew (一). 初回手術10力月後血便あり, 吻合部に全周性 埂瘍認め, 1990年12月直腸切断術施行. a2, ow (-), aw $(-)$, ew $(+)$. 症例 $3: 54$ 歳, 男性. 1987年 8 月 
Rs， circ， 2 型に対し前方切除術施行. $s$, ly $\mathrm{y}_{2} ， \mathrm{v}_{0}, \mathrm{n}_{0}$, ow (一), aw (一). 初回手術 2 年 4 力月後下血あり, 吻合部直上に 2 型腫瘍認め，1990年 3 月再手術施行. 腫 瘍は仙骨前面に浸潤し切除不能にて S状結腸に stoma 造設.

\section{6. 大腸カルチノイド 6 例の手術経験}

市立地川病院外科

平 康二, 熱田 友義, 伊藤 紀之 子野日政昭，沼田 昭彦，森山 博史 宮崇 直樹

われわれは最近約10年間に大腸カルチノイド6例を経 験したので報告する，男：女＝2：1で，年齢は37〜68 歳 (平均57歳) であった，原発部位は直腸 4 例，上行結 腸 1 例, 出垂 1 例であった，直腸カルチノイド 4 例中 3 例は腫瘍径が $20 \mathrm{~mm}$ 未満であった。いずれも深達度 $\mathrm{sm}$ で局所切除後再発は認めていない. 腫瘍径が $20 \mathrm{~mm}$ 以上 の1例は多発性肝転移症例である．上行結腸カルチノイ ドに対しては右半結腸切除・ $\mathrm{R}_{2}$ 郭清を施行した. 術後 5 年目に他病死した. 虫垂カルチノイド症例は腫瘍が虫 垂に限局していたため再手術法わなかった. 術後 2 年 2 か月経過したが再発は認めていない，消化管力ルチ， イドの治療法の選択は発生部位，腫痬径，樑達度などを 考慮し慎重に行う必要がある。

\section{7. 大腸癌における腫瘍マーカーの検討}

北海道大学第 1 外科

小川 秀彰, 近藤 征文, 白戸 博志 大沢 昌平, 益子 博幸, 近藤 正男 福富京, 内野 純一

大腸癌の腫湯マーカーの術前測定の意義について検討 した. 対象は1990年 1 月～1991年12月の大腸㴦初回手術 例55例で，CEA，CA 19-9，CA 50，NCC-ST-439を 測定した．術前の陽性率はそれぞれ $42.5 \% ， 24.5 \%$ ， $11.3 \% ， 25.4 \%$ であった. 肝転移 (十) 群と（一）群の 陽性率はそれぞれ CEA が87.5\%と 34.7\%，CA 19-9 が $62.5 \%$ と $17.7 \%$ ，CA 50が50.0\%と $4.4 \%$ であり有意 差がみられた. stage 別では Dukes A，B群と DukesC 群の陽性率はそれぞれ CEA が23.0\%と59.2\%，CA199 が $8.0 \%$ と $37.0 \% ， \mathrm{CA} 50$ が0\%と22.2\%であり有意 差がみられた，術前のマーカー陽性例の治瘉切除率 は CEA が47.8\%， NCC-ST-439が46.1\%，CA 19-9が $23.0 \%$ ，CA 50が0\%であり，CA 19 -9 とA 50陽性 例は進行例が多い．また早期癌と進行癌で陽性率に有意 差のあるマーカーはなく，早期癌のマーカー陽性例 は
CEA, NCC-ST-439が1例で, CA 19-9, CA 50では 陽性例はなかった，CA 19-9 と CA 50は大腸癌の早期 発見のマーカーとしては有用性は少ないと考えられた。

\section{8. 肛門癌の検討}

一とくに下方リンパ節転移についてー

札幌医科大学第 1 外科

蔦井 克典, 佳々木一晃, 江副 英理

亀䳋 秀和，木村 雅美, 山城一弘 山本 雄治, 桂 巻 正, 三神 俊彦 筒井完，平田 公一

肛門癌の治療で鼠径リンパ節の予防的郭清は, その後 の愁訴の多さより施行しないことが多い. 教室では触診 で鼠径りンパ節を触知せず，開腹所見で外腸骨動脈りン パ節に所昌がないなら予防的郭清を行っていない，そこ で今回，教室の肛門癌を検討した. 対象 : 最近の15年間 に教室で初回治療がなされた肛門癌20例を対象とした. 結果 : 治澺切除後の鼠径リンパ節転移は $6 \sim 8$ 力月後に 認め，郭清が行われ全例 $1 \sim 5$ 年生存中である. ま之 め: 肚門癌切除後に鼠径リンパ節転移を見るものの，予 防的郭清を行わなくとも注意深い術後経過観察で予後に 差を認めない可能性が示唆された。

\section{9. 肛門癌の検討}

\section{国立札幌病院外科}

寺山 裕同, 北河 徳彦, 渡 辺 出 近藤 啓史，内藤 春彦，佳々木廸郎

同 消化器科

池田 成之

同病理部

藤田 昌宏，山城 勝重

大腸癌取り扱い規約によれば肛門管は，肛門括約筋の 上縁の恥骨直腸筋付着部より下方の肛門に及ぶ管状部と 規定されている．肛門癌は欧米では肚門と肛門管を区 別し，外科的肛門管に病巣の中心がある癌を一括して組 織型のいかんにかかわらず肚門管癌とすると定義してい るわが国とは取り报いに执いて若干の差を認める。今回 当科では1965年〜92年までに肛門癌を19例経験した．男 性10例，女性 9 例である。年齢は37歳〜84歳で平均年夦 は55.9歳であった．解剖学的には直腸の下部の悪性腫瘍 は, 痔静脈などに入りやすく大循環を介して肺転移しや すいといわれている．本症例は，記載上多発遠隔転移を 起こしやすく予後が非常に腎かった，これらの症例をも とに直腸癌の特に $\mathrm{Rb}$ に位置するものと比較し若干の 検討を加え報告する． 